\title{
In memoriam: Dr. Raúl A. Borracci
}

Manuel R. Montesinos

Pocas veces la vida nos ofrece el privilegio de conocer de cerca a alguien excepcional.

Y la pérdida de esa persona excepcional nos despierta de inmediato la insoportable tristeza de no haber aprovechado más su invalorable proximidad.

Tal fue mi sentimiento al enterarme, el 19 de marzo, del fallecimiento a los 62 años de Raúl Alfredo Borracci.

Nos conocimos durante la residencia de Cirugía en el Hospital de Clínicas José de San Martín, cuando compartimos, a principios de los 80 , esa etapa liminar en nuestra formación y que resulta siempre una huella indeleble para los cirujanos.

Su carácter sereno y afable, pero a la vez seguro y decidido, lo distinguió siempre y le valió la consideración de todos quienes lo conocieron. Estudioso y trabajador incansable, poseía también el don del análisis inteligente y apropiado.

Su exitoso desempeño en la cirugía cardíaca como Jefe de Clínica de la División Cirugía Cardíaca del Hospital de Clínicas y Jefe de Cirugía Cardíaca del Hospital Alemán le ganó el respeto de los colegas y la admiración de sus discípulos, de quienes fue un generoso mentor.

Fue además un estudioso de la estadística y la metodología de la investigación, así como de la educación médica.

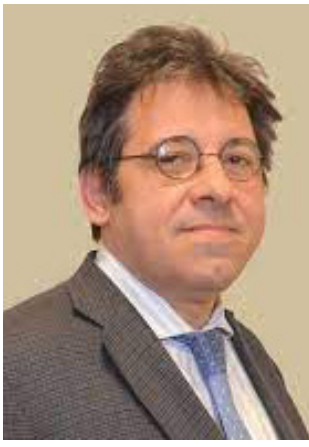

Integrante del Comitè Editorial de la Revista Argentina de Cirugía

Fue Doctor en Medicina, docente de universidades estatales y privadas, publicó más de 160 trabajos, varios de ellos citados en PubMed, y fue coautor de 7 libros sobre cirugía cardíaca y educación médica. Obtuvo varios premios y fue revisor de revistas argentinas y extranjeras.

Su destacada capacidad lo llevó a ser director de la Revista Argentina de Cardiología y ser un destacado miembro del Comité Editorial de la Revista Argentina de Cirugía. Precisamente era en muchas de nuestras reuniones del Comité cuando esperábamos siempre su opinión prudente y certera sobre las distintas alternativas editoriales que nos tocaba enfrentar $y$ decidir.

Además de sus logros científicos y académicos, aquellos que pudimos tratarlo disfrutamos de su estilo amable, respetuoso, sus rasgos de fino humor y sus opiniones sinceras y honestas sobre nuestra realidad.

Sin duda, a quienes lo conocimos cercanamente nos resultará muy arduo sobrellevar su temprana pérdida.

Por último, sobre Raúl pienso que aplicaría lo dicho por Cicerón: "Hay dos clases de hombres: los que nacen, se reproducen y mueren, y otros que nacen, producen y nunca mueren". 


\section{- ENGLISH VERSION}

Life seldom offers us the privilege of getting to know someone exceptional.

And the loss of that exceptional person immediately awakens in us the unbearable sadness of not having made the most of his or her invaluable proximity.

Such was my feeling when I learned, on March 19 , that Raul Alfredo Borracci had passed away at the age of 62 .

We met during our residency in surgery at Hospital de Clínicas José de San Martín in the early eighties, when we shared that liminal phase in our training which is always a permanent mark for surgeons.

His calm and friendly -though confident and determined-character, always made him stand out and was well respected by all those who knew him. He was a scholar and tireless worker, but he was also gifted with the ability to provide intelligent and appropriate analysis.

Due to his successful performance in cardiovascular surgery as Chief of Surgery of Hospital de Clínicas and as Chief of Cardiovascular Surgery of Hospital Alemán, he gained the respect of his colleagues and the admiration of his disciples, for whom he was a generous mentor.

He was also a scholar in statistics, research methodology, and medical education. He completed a Doctorate Program in Medicine, was a faculty member at public and private universities, published more than 160 papers, several of them cited in PubMed, and co-authored 7 books on cardiovascular surgery and medical education. He was granted with several awards and was a reviewer of Argentine and foreign journals.

His outstanding ability led him to become director of the Argentine Journal of Cardiology and to be an outstanding member of the Editorial Board of Revista Argentina de Cirugía. It was precisely in many of our board meetings when we were always waiting for his prudent and accurate opinion about the different editorial options we had to deal with and decide on.

In addition to his scientific and academic achievements, those of us who got to know him enjoyed his kind and respectful style, his fine sense of humor and his sincere and honest opinions about our reality.

Undoubtedly, it will be hard for those of us who knew him closely to cope with his early loss.

Finally, I think that Cicero's words apply to Raul: "There are two kinds of men: those who are born, reproduce and die, and others who are born, produce and never die". 